Jordan J. Ballor, Matthew T. Gaetano, and David S. Sytsma, eds.

Beyond Dordt and de auxiliis: The Dynamics of Protestant and Catholic Soteriology in the Sixteenth and Seventeenth Centuries. Studies in the History of Christian Traditions, 192. Leiden: Brill, 2019. Pp. viii + 36o. Hb, €149.oo.

The last few years have witnessed a resurgence of interest in the bedrock question of how to understand the relationship of human freedom and divine causality. Recent works by Matthews Grant, Hugh McCann, Richard Muller, Taylor O'Neill, Michael Torre, and several others have revisited the question from philosophical and theological angles, and within the purview of theology, from Catholic and Protestant perspectives. Beyond Dordt and de auxiliis breaks fresh ground by examining this question within the burgeoning field of early modern Scholasticism.

In contrast to the recent studies mentioned above, the purview of this volume is mainly historical rather than philosophical or theological. So, while the authors provide insight into the positions themselves and into the protagonists' relations to each other, we do not find an answer to the question of who was, at least in relevant respects, right or wrong about grace, predestination, and freewill. However, the contributors to this volume do include philosophers and theologians from different confessional backgrounds in addition to intellectual historians. This balance and complementarity of perspective is one of the volume's great merits. Not all of the essays are equally conclusive, but this is to be expected given the originative nature of the research and the fact that the literature is vast, conceptually complex, and largely untranslated. Simply getting clear on what the positions were is a necessary propaedeutic for making any deeper philosophical or theological determinations. The quality of the essays is uniformly high. It is exciting to see gathered into a single collection the work of both seasoned experts and those at an earlier stage in their careers. The appearance of this volume and the fact that several of its contributors are younger scholars signals that thinkers are finally seeking a better understanding of the neglected achievements of post-Reformation-era Scholasticism.

This volume comprises thirteen essays which explore the trans-confessional continuities between Catholic and Calvinist positions on grace, predestination, and freewill. The editors rightly present the protagonists of these positions as locked in debate over the authentic appropriation of Augustine, and the contributors present the extremely complex landscape of these debates with commendable lucidity. Complexity characterizes not only the positions themselves, but also their various relations of dependence on, similarity to, or distinction from each other. 
While all the protagonists claim Augustine for their own and seek to reason within a broadly catholic mode, the specific views engaged are those of Thomas Aquinas, John Calvin, and their later followers. The followers are Thomists (principally Dominicans), Molinists of various stripes (principally Jesuits), Jansenists, the Reformed, and Arminians. The essays of this volume may be broadly categorized into those that detail the reception of Aquinas among Catholic (including Jansenist) thinkers, those that detail the Reformed appropriation of Thomist sources, and those that detail Remonstrant appropriations of Molinist sources, although some of the essays defy this neat categorization. The essays are unified by their attempt to show that the fault lines of debate fall with greater definition within the two confessions than between them. Sometimes, these fault lines fall in unexpected places, with Protestants, who would seem to have much in common with the Dominican Thomists, standing apart from them, and in some cases, more closely to the Jesuits due to shared presuppositions inherited from thinkers after Aquinas.

Aquinas's view and its reception by Domingo Báñez is documented with admirable clarity by Reginald Lynch, O.P. By comparing the thought of Aquinas and Báñez with that of Gisbertus Voetius, Lynch argues that Descartes effected a paradigm shift away from the Bañezian-Thomist view. But given that Voetius was an opponent of Descartes and knowingly adopted crucial aspects of Báñez's position, some questions remain about precisely how Cartesianism altered Reformed thinking about God's movement of the will and differentiated it from the Thomist school. Lynch does provide some preliminary indications, and his essay opens a promising avenue for further research.

Other Reformed thinkers also appropriated Thomist thought in support of their positions on grace and predestination. Jordan Ballor demonstrates this dependence in Calvin's student, Franciscus Junius, thereby overturning the narrative that Protestant thought was unilaterally nominalist and antiScholastic. David Sytsma reveals how Aquinas and his followers were appropriated by Reformed English divines in support of the teachings of the Synod of Dordt, while Stephen Hampton details the agility and accommodation with which Samuel Ward defended Dort's teachings in England through his theology of baptism and election.

However, while followers of Calvin may have shared common ground with followers of Aquinas and perhaps with Aquinas himself, Charles Raith II convincingly argues that there was no direct dependence of Calvin on Aquinas. Rather, we learn that Calvin encountered Aquinas only though Martin Bucer and a different, unnamed, nominalist mediator. Matthew Gaetano shows how in the wake of the de auxiliis debate Dominican authors themselves came to acknowledge certain affinities of their view with that of Calvin's followers. 
These Dominicans drew crucial distinctions between Calvin's position and that of the Calvinists, and judged that where the Calvinists departed from Calvin, they drew nearer to Thomas.

Eric DeMeuse takes up Jansenism, characterizing it as a mediating position that combined elements of Calvinism, Molinism, and Thomism. Yet, like the way that there was a shift within the Reformed tradition between Calvin and his more Scholastic followers, so too DeMeuse argues that there was a shift between thinkers of first and second-generation Jansenism that aligned second-generation Jansenists with Thomism, at least in substance, if not in nomenclature.

While affinities of the Calvinist and Jansenist views with Thomism was a liability for the Dominicans in the de auxiliis debate and beyond by lending weight to Jesuit accusations of heresy, Matthew Gaetano also shows that the Dominicans redirected the accusation back onto the Jesuits, pointing out that both the Jesuits and Calvin denied the compatibility of human free choice with divine predetermination. Thomas Osborne notices a similarly counterintuitive agreement between Jesuits and Protestants on the assumed framework of the debate over acquired faith, even while they each grasped different poles established by that framework. Showing the diversity of Catholic views on acquired faith, Osborne perceptively explains how disagreements between Jesuits and Protestants led Dominican Thomists to sharpen their arguments against acquired faith, (defended by the Jesuits) in apparent, but merely superficial, continuity with the Protestants, who rejected it.

It would be a mistake, however, to think of the Thomist position (or any of the main positions in the post-Reformation predestination debates) as monolithic. Focalizing the Christological context of the predestination debates, Trent Pomplun detects a shift between Thomas and the Thomists, attributing this in significant part to the influence of John Duns Scotus. In one of the highlights of this volume, Stephen Gaetano shows that there were also variances among the Thomists themselves, especially in the years preceding the de auxiliis debates. The Jesuits tried to leverage the incongruities between Domingo Báñez and his forebears, such as Thomas Cajetan, Domingo de Soto, and Pedro de Sotomayor, and this led to an effort on the part of the Dominicans to consolidate their position.

Other essays trace the Protestant reception of Jesuit thought. Richard Muller conclusively establishes Molina's influence on Arminius, arguing that Arminius's reception of Molina during the Controversy de auxiliis founded the correlative debate within Protestantism. In a complementary fashion, Keith Stanglin documents the wider direct reception of Molinism among Remonstrant theologians. Both contributions overturn recent suggestions that 
Molina's influence was only distant and indirect. However, as Stanglin points out, this relationship was sometimes a lukewarm one, both in respect to middle knowledge, and, as Aza Goudriaan shows, in respect to metaphysics-a Jesuit enterprise from which Arminius eventually distanced himself. Goudriaan also reveals how, conversely, Reformed thinkers praised and appropriated the achievements of Jesuit metaphysics and legal theory, even while disagreeing with them on grace and freedom.

This volume delivers on its aims and historians, theologians, and philosophers concerned with Catholic and Protestant doctrines of grace will find it to be a useful resource. This volume also prepares the way for attempts to move even further beyond Dordt and de auxiliis, especially through an exploration of the cognate quarrels within Lutheranism, the relationship of all the predestination debates to atheistic humanism, and the possibilities for ecumenical rapprochement.

\section{R.J. Matava}

Notre Dame Graduate School of Christendom College rmatava@christendom.edu

DOI:10.1163/22141332-00702012-12

\section{Daniel Schwartz}

The Political Morality of the Late Scholastics: Civic Life, War and Conscience. Cambridge: Cambridge University Press, 2019. Pp. xiv + 234. Hb, $\$ 100.00$.

As its title implies, the work under review traces various debates between late Scholastic thinkers on questions of political morality that remain surprisingly relevant for our own day. Naturally, the book surveys Jesuit Scholastics such as Luis de Molina, Francisco Suárez, Gabriel Vázquez, Diego Laínez, Luis Torres, Pedro Hurtado de Mendoza, along with various lesser lights. Without arguing that citizens of the twenty-first century can import late Scholastic analyses wholesale, the author nevertheless holds they shine an indirect light on our moral quandaries, highlighting assumptions that we take for granted but should not (5). The book pursues this exercise of retrieval over the course of nine chapters, devoting the first five chapters to civic life, and the last four chapters to war.

The chapters devoted to public life treat a wide range of topics. Chapter 1: "The Ethics of Electoral Bribing" shows that late-Scholastic and contemporary political theorists agree that we ought not buy votes but do so for different reasons. Whereas contemporary philosophers argue that one cannot market 